\title{
The Role and Function of Board Education To Improving Education Services Quality
}

\author{
Endang Sri Budi Herawati ${ }^{1}$, Suryadi $^{2}$, and Bejdo Sujanto ${ }^{3}$ \\ \{endang.sri.budi.herawati@mahasiswa.unj.ac.id ${ }^{1}$, hcsuryadi.unj@gmail.com² ${ }^{2}$, bejosujanto@unj.ac.id ${ }^{3}$ \} \\ ${ }^{1} \mathrm{PhD}$ Student of Education Management, Universitas Negeri Jakarta, Jl. Rawamangun Muka, \\ Jakarta Timur 13220, Indonesia \\ ${ }^{2,3}$ Education Management Department, Universitas Negeri Jakarta, Jl. Rawamangun Muka, \\ Jakarta Timur 13220, Indonesia
}

\begin{abstract}
Education service quality can be improved by strengthening community participation in decentralized education framework. It can be carried out by optimizing the role and function of Board Education which is the front line for community participation at the district level. A case study method with a descriptive qualitative approach was used to this research. This paper shows that the role the Board of education is not optimal. Regarding the implementation of the advisory agency, Board of education does not collect data on the socioeconomic condition and educational resources in society. That data can be analyzed and used as an input material, consideration and recommendations to the regional government and the Department of Education. So that, the input submitted will be more accurate following the actual problems community.
\end{abstract}

Keywords: Board of Education, Education Quality, community participation

\section{Introduction}

Political Reformation in Indonesia at the end of the 20th century has brought significant changes to the education sector development policy. Generally relies on two new paradigms, autonomy and democracy. Education is one sector that is autonomous with other regionalbased development sectors such as forestry, agriculture, cooperatives and tourism[1]. At the same time, the government also issued law Number 20 of 2003 concerning the National Education System. One important issue in the law is the involvement of the community in the development of the education sector, as stated in article 9 that the community has the right to participate in the planning, implementation, supervision and evaluation of educational programs [2].

At the regulatory level, article 56 of Law Number 20 of 2003 concerning the National Education System, affirms that the community plays a role to improve educational services quality which includes planning, supervision and evaluation of educational programs through a board of education and school committee [2]. Also, it was also emphasized that the Board of Education as an independent institution formed and played a role to improving educational services quality by giving consideration, direction and support of personnel, facilities and infrastructure and supervision of education at national, provincial, district and city levels that not have hierarchical relations [3]. 
The central concept of decentralization education is community considered the most certain party to the implementation and implementation of the education system, in particular, primary school and secondary, an elementary school in each region - society as a source of inspiration, innovation, and motivation, as well as goals from the quality education system in the area. The community also as a source of funds to implementing education in each area. Thus making the point that society is a stakeholder of an educational system in the region. Educational implementation in regions requires adequate support from the city. An alternative way of obtaining community support for the education sector is to develop real relief from all community level (including the private sector and industry) towards implementing quality education. However, complexity in society has no distinct boundaries and challenging to determine which community as a stakeholder in the education sector. For this reason, politically, the community's precise alignments need to be conveyed joint movement that accommodated in Education Council in Regency.

\section{Board of Education}

The Education Council is a manifestation of community participation in decision making in the field of Education to improve the quality of Education services. The aims establishment Board of education according to the Decree of the Minister of National Education No. 044 / U / 2002 is: (a) facilitating and conveying the aspirations and initiatives community to make education programs and policies; (b) increasing responsibility and community participation for education performance; and (c) Creating a transparent, accountable and democratic atmosphere and conditions in the implementation and provision of quality education services [4]. Furthermore, the role of Board education is: (a) An advisory agency in determining and implementing education policies; (b) Supporting agencies, both in financial, thought and energy in the implementation of education; (c) a controlling agency in the context of transparency and accountability in administration and output of education; and (d) Mediating between government (executive) and the Regional People's Representative Council (legislative) with community [5]. Some functions of the Board Education are: (a) Encourage commitment and increasing community attention towards implementation of educational quality; (b) Cooperate with a population (individuals/organizations), government and DPRD concerning the application of quality education; (c) Accommodate and analyze community aspirations, ideas, demands, and various educational needs; (d) extend consideration and recommendations to the regional government /DPRD regarding: educational programs and policies, regional performance education standard, education staff standard particularly teachers and heads of education units, educational facilities standard, other matters related to education; (e) Encouraging parents and community to participate in education, to support quality improvement and educational equity; and (f) Evaluate and supervise education policies, programs, implementation, and output [4].

Based on the explanation above, it can be concluded that the Education Board is an institution that was deliberately formed to play an active role in improving the quality of education. The strategic position of this institution is to make the Board of Education as a front liner for public participation to contribute actively to the development of knowledge in each region [6][3][7]. Boards of Education can also be found in other countries. In the state of California, United States the role of education boards is generally "regulating schools" (California School Boards Association, 2009). The main responsibility of the Board is 1) to determine all policies of schools in the district; 2) compile an annual budget to obtain public 
approval; 3) approve and reject recommendations from the supervisor or authority over them regarding staffing and contracts relating to schooling; and 4) being a mediator between the community and the supervisor or district leader (source: http://www.bhbl.org/district/board/ boardduties.htm) [3].

The Board of Education at Cirebon Regency has been formed since 2002 and currently in fourth management period. However, the education index in Cirebon Regency was relatively stagnant with the Average School Length (RLS) in 2015 was 7.01 figures of School Length Expectation (HLS) 11.79 and Literacy Rate 94.07 [8]. From these data, the people of Cirebon Regency have minimum average expectations of high school graduation. But in fact, the average community only graduated from elementary school and dropped out in the first grade of junior high school. And that is an indication that the 9-year basic education program is not yet complete (seen from RLS 7.01). This could be an indication that the 9-year basic education program is not however complete. And this, of course, becomes a pretty heavy homework for the Cirebon District government and all components of the community to be able to improve educational achievement. Concerning the need for community participation in education, it is interesting to study how the Education Council has carried out its role and function so far so that it can contribute to better educational outcomes. The study on the Board of Education shows that the contribution of this institution to improving the quality of education is still not optimal. The existence of this institution has not been fully accepted by both the Education and School Offices, so that it has not been able to carry out its roles and functions optimally [3][7][9][10].

\section{Method}

A qualitative descriptive with a case study was used in this research - the procedures of qualitative descriptive produce spoken words and behavior of observed subjects as a data graphic. The research subjects consisted of the chairperson and secretary of the Board of Education, the Education Office and members of the Commission D DPRD Cirebon Regency. Observation, in-depth interviews, and documentation studies are collecting data method. Then, triangulations used to validity testing while inductive analysis techniques used to analyze data. A Self-Assessment adopting from The Education Board Operational Reference and Performance Indicators Book (Dirjen Dikdasmen, Depdiknas) was also used in this study [11].

\section{The Role and Function of Board Education}

Board of Education has a function to encourage growing community attention and community commitment to implementing education quality. This institution can establish cooperation with the community, both individuals and organizations, the business world and the industrial world (DUDI), government, and DPRD regarding the implementation of quality education. Another Board of Education function is to accommodate and analyze aspirations, views, demands, and various educational needs proposed by the community.

Cirebon District Board of Education in implementing its role and function has developed a program appropriate with the aims of established this institution, that to encourage growing community attention and community commitment to achieving an education. However, most of the program programs that have been prepared cannot be carried out due to limited funds and human resources. The results of the self-assessment conducted by Chairperson of Cirebon 
Regency Education Board showed that the operational activities of Cirebon District Education Board were in the "Less Successful" category with an index score of 52.5. Despite regarding the Education Board Organizational Facilities was in the category "Successful" with an index score of 82.5. It means that the Education of Board was not able to used facilities optimally so that to carry out their roles and functions is not optimal.

It is understandable that the Education Council does not have budget allocations from both the central and regional governments. Board of Education activities is funding by donation that has not the same amounts for each budget. Also, this grant cannot be submitted every year. So, if in the first year has provided a gift, the second year may not present, then the third year will continue and so on. It makes Board of Education implement the programs that have been prepared.

To carry out the mission to realize the vision, the Education Council has compiled various work programs. This program has been socialized to various relevant agencies including local government. Audience with regent of Cirebon (local government) and Cirebon Regional Representative Council (DPRD) are conducted at the beginning of the tenure of each management period. However, the lack of budget and human resources Board of Education is one of the constraints to implementing the program. In case there is no grant, then the program that can be achieved is only programs which are the collaboration of the Education Council with the Education Office. It means that the program implemented using the budget from the. One program that does not carry out properly is School Committee Empowerment. As a program from the Cirebon District Education Office, that program in realization did not involve Board of Education. According to Board of Education secretary, there is no readiness from Education Office to delegate authority about fund allocation for empowerment of school committees from the district income budget of Cirebon (APBD Cirebon Regency).

Article 56 Paragraph, 3 Law Number 20 of 2003 concerning National Education System, states that School Committee, as independent institutions, are formed and played a role to improve educational quality services with consideration, giving support and direction, facilities and infrastructure, and instructional supervision in education unit level. That committee played a role and function as same as a Board of Education. The committee was playing a significant role in improving educational quality In unit education level. Therefore, it is crucial to the Board of Education to communicate, coordinate, and guiding school committee. Board of Education will interact more intensely with the school Committee if Education Office delegates authority including budget allocation to them. The lack of communication between the board of education with School Committee only to extend fulfils invitation in ends year or a middle year or a new school year. Discussion in elementary school levels carried out through the school committee forum.

The other programs that have not been implemented are research and development program and collecting data educational institutions programs. In this case, an implementation program caused more by the lack of human resources. That problem can be resolved through cooperation between the Education Council and higher education institutions in Cirebon Regency. There are around three private universities, one state religious institute, and several health colleges in Cirebon Regency. The Board of Education should be able to collaborate with universities to conduct research related to topics that already been established, which will benefit both to the Board of Education and higher education institutions. The documented research study also can be input for local governments, so research and development programs can be implemented well. Unfortunately, yet coming undone by Board of education. Therefore, the Board of Education needs to build communication and coordination with higher education institutions in the Cirebon Regency area. 
Regarding the implementation of roles and functions, the Cirebon District Board of Education has carried out part of its role as an advisory agency. Some suggestion being transferred to the DPRD, Regional Government, Education Office and Ministry of Religion are to seek formulations of Regent Regulations relating to Cirebon Regency Regional Regulation Number 13 of 2011 concerning educational Implementation associated with the following matters: (a) Organize reading, writing and counting civilization; (b) carrying out and controlling educational services quality; (c) that every student has the right to get religious education according to their religion; (d) students' health and mental rights; (e) quality local based education; (f) potential and preeminent school; (g) local content curriculum and nonformal education unit curriculum; (h) Supplying facilities and infrastructure for private education units; (i) Providing SBPP, scholarships, and budget for potential and preeminent school, managing school fund sourced from community donation that managed and implemented by school committees; (j) educational evaluation, accreditation, and certification; (k) supervision; (l) and administrative sanctions.

Other suggestions made by Education Board include: (1) New Student Admission (PPDB): the number of classes and students in each category, individual tests (ex: physical tests, health tests, etc.) for vocational schools that are considered burdensome in the PSB recruitment process, and optimization of non-academic paths according to student zoning; (2) implementation of National Examination: preparing additional infrastructure, CBT socialization particularly to students who does not have laptops, material profundity and enrichment for students, and optimizing the role of supervisors to school as efforts to improve UN results; (3) teacher certification: controlling to certified teacher regularly and periodic to enhance professionalism and competence, improve in house trainning (IHT), teacher working group (KKG), subject matter teacher discussion (MGMP), or consultation counseling teacher (MGBK) as tools to develop materials, tools and learning media; (4) promoting activities of 6 $\mathrm{K}$ (discipline, cleanliness, beauty, security, welfare, and family); (5) educational innovations: prioritizing supervision inclusive school programs, greening schools especially in border areas and on the roadside, and monitoring superior/pilot school programs (especially in financial management, need to be accompanied by Regents or Regulations); (6) intensifying the reading and writing culture program: optimizing the use of school libraries, managing good libraries, and increasing the number of library collection books; (7) Islamic Education Subjects: procuring the Qur'an and other books in the school with a ratio of 1: 1, efforts to secure a prayer room or prayer / religious corner in each school, the implementation of a Koran reading and writing culture in each school, and strengthening the application of the central theme of Islamic Religious Education in schools; (8) curriculum development of local content as an effort to preserve and develop culture; and (9) optimizing the empowerment of school committees.

The important thing that has not been done by the Education Council regarding the implementation of this advisory role is to collect data on the socio-economic conditions of the community and educational resources in the city. Furthermore, the data is analyzed and becomes input material as well as considerations and recommendations given to the regional government and the education office. Thus, the input submitted will be more accurate following the actual problems faced by the community.

Role implementation Board of Education as a Supporting agency not been optimal because school committee meetings as incidentally act. So, extending motivation being not optimal. And neither motivation through electronic media like television and radio. Board of Education needs collaboration with management TV and Radio station by interventions from regional development and Disdik. The government needs to facilitate the Board of Education 
to motivate society through regular broadcast programs. For examples collaborate with Government Radio Station (RRI) and Cirebon Television Station (CRTV). The organization will motivate more with that program routine to contribute in education and realize the importance of education for children's future as the next generation of nations.

Furthermore, roles as a Controlling agency has not been optimal. There is no coordination between the Board of education and School committee routinely. Hence, necessary to establish secure communication with school committee forum until communication and coordination with school committees elementary school going well. While the schedule in school committee at junior secondary level needs to agree with the plan of monitoring and evaluation of any Education Office activities involving Board of Education, as related to issuance of Law No. 23 of 2014 concerning Regional Government, states that local government are responsible in elementary education, while the provincial government are responsible for high school level education and Board of Education need to communicate with the head Branch Office of Education of West Java Province Region X which has the work area of Kuningan Regency, Regency, and City of Cirebon. It's to ensure involvement Board of Education to coordinate and communicate with senior secondary school committees and the application of curriculum for local life skills. So far, Board of Education still coordinating with high school level committees in Cirebon Regency Area.

As a Mediator role, Board of Education yet not implemented optimally, just limited early stage to build communication with DUDI. Based on Data, DUDI has indeed contributed to improving educational quality in Cirebon Regency. Including giving scholarship for needy students and granting New Classrooms (RKB) to some elementary school. That was information from the Cirebon District Education Office. However, DUDI through its Corporate Social Responsibility (CSR) contribute only in ring one of each company. Of course, that's come about inequality particularly to areas that come far from the company, though the city needs help to improve educational infrastructure. The implementation of Law No. 40 of 2007 concerning limited liability companies and Law No. 47 of 2012 concerning limited social and environmental responsibility has limited to the lack of company policy only to prioritise CSR programs in company's ring one in the region. Therefore, Board of Education necessary to coordinate with Education Office, BAPPEDA, Regional Government (Pemda) to communicate that matter. Indeed, Regent Regulation be needed to reorganize CSR fund allocations for each company to improve educational quality under coordination between relevant department (Education Office) and Board of Education.

\section{Conclusion}

Board of Education not been able to carry out role optimally. As an advisory agency's position has been carrying out is included in the content of the local curriculum, mutations, and rotations of educators and school principals. The other way regarding the implementation of the advisory's role is collecting socio-economic conditions data and educational resources in the community. Furthermore, if that data available, it can be analyzed and become advertising and suggestions as considerations and recommendations to regional government and educational office. As well as the guidance be more accurate following the actual problem faced by the community. Whereas as a Supporting Agency's role also neither optimal. That role only limited by committee meetings incidentally and of course extending motivation to society be un-optimally. Functions as a Controlling Agency lacked in coordination with school committees not routinely. And as a mediator's role Board of Education only limited to the first stage to build a communication with DUDI. The lack of fund allocation to financing Board of 
Education activities can be made with optimizing the role of the business community through the actions of Corporate Social Responsibility (CSR) companies in Cirebon Regency. A Regent Regulation need to organize that some of CSR funds have to allocated to improving educational quality and implementing under coordination between BAPPEDA, Educational Offices, and Cirebon Education of Board. So that, educational development will be more evenly distributed throughout the region.

\section{References}

[1] UU No 22 tahun 1999 tentang Pemerintah Daerah. 1999.

[2] UU SISDIKNAS NO 20 TAHUN 2003. 2006.

[3] Hendarman, "The Role Of Education Board In Improving The Quality Of Service," vol. 18, pp. 34-44, 2012.

[4] Kepmendiknas No 044/U/2002. 2002.

[5] J. T. Nugraha, "Peran Komite Sekolah Dan Dewan Pendidikan Dalam Upaya Peningkatan Kualitas Pendidikan Di Kabupaten Sleman," Probisnis, vol. 6, no. 1, pp. 33-52, 2013.

[6] W. Iwan Panji, "Persepsi Publik Terhadap Peran Dewan Pendidikan Kota Yogyakarta / Public Perception Of The Role Of The Education Board Of Yogyakarta City," J. Hanata Widya, vol. 5, no. 7, pp. 10-18, 2018.

[7] A. Suryono, R. Santosa, and Haryadi, "Implementasi Peraturan Pemerintah Nomor 66 Tahun 2010 Terhadap Pemberdayaan Dewan Pendidikan Dan Komite Sekolah,” J. Din. Huk., vol. 13, no. 2, 2013.

[8] Profil Sosial Budaya Kabupaten Cirebon Tahun 2016. Cirebon, 2017, p. 62.

[9] Setditjen Dikmen \& UNY, "Kajian Evaluasi Dampak Kontribusi Dewan Pendidikan/Komite Sekolah Terhadap Peningkatan Mutu Pendidikan Sekolah Menengah," Jakarta, 2011.

[10] Isnaeni, "Analisis Kinerja Komite Sekolah Pada Sekolah Dasar Di Kota Malang," Pasca Sarjana Universitas Muhammadiyah Malang, 2012.

[11] Acuan operasional kegiatan dan indikator kinerja komite sekolah. Nasional, Departemen Pendidikan Jenderal, Direktorat Dasar, Pendidikan Menengah, D A N Pengembangan, T I M Pendidikan, Dewan Komite, D A N, 2003. 